\title{
Induction Heating of the Filling Conveyor Molds
}

\author{
Viktor N. Timofeev, \\ Ilya A. Strombskoy*b and Anna B. Alekseeva ${ }^{a}$ \\ ${ }^{a}$ Siberian Federal University \\ Krasnoyarsk, Russian Federation \\ ${ }^{b} O O O \ll R U S A L I T C »$ \\ Krasnoyarsk, Russian Federation
}

Received 01.06.2021, received in revised form 15.07.2021, accepted 30.07.2021

\begin{abstract}
In the smelting and foundry production of aluminum ingots, filling conveyors are widely used. Aluminum ingots of a certain shape and weight are obtained by crystallizing liquid aluminum (melt) in the molds of the filling conveyor. As the mills move along the conveyor, the melt gradually hardens in them. In high-performance conveyors, the mills move through the water to increase the cooling rate of the melt. Therefore, after the mill is freed from the hardened ingot, water enters it. In order to avoid temperature shock and possible release of liquid metal, the molds must be dried and heated before pouring. At present, gas burners are used in aluminum plants for this purpose [1]. The purpose of this work is to study the possibility of induction heating of the filling conveyor molds.

The calculation is carried out using Fourier series in complex form and approximate boundary conditions on the surface of ferromagnetic molds. The approximate boundary conditions avoid the need to calculate the electromagnetic field in a nonlinear ferromagnetic medium.

In the heated object, the energy of the induced alternating electric field is irreversibly converted into thermal energy. This dissipation of thermal energy, which leads to the heating of the object, is determined by the presence of conduction currents (eddy currents).

Induction heating is widely used in metallurgy for melting, heating and mixing of electrically conductive bodies. The method is based on the absorption of electromagnetic energy by bodies of an alternating magnetic field created by an inductor. The heated product is located in the immediate vicinity of the inductor. There are many publications on analytical and numerical, analysis of physical processes in the inductor-heated billet system. In this paper, an analytical calculation of electromagnetic processes in the system of inductor - ferromagnetic molds of the filling conveyor is carried out. The analytical solution is obtained by using the approximate boundary condition of L. R. Neumann on the surface of nonlinear ferromagnetic molds.
\end{abstract}

Keywords: filling conveyor, Induction heating, inductor - mold system, aluminum ingot, magnetic field.

Citation: Timofeev V.N., Strombskoy I. A., Alekseeva A. B. Induction heating of the filling conveyor molds, J. Sib. Fed. Univ. Eng. \& Technol., 2021, 14(5), 583-589. DOI: 10.17516/1999-494X-0335

(C) Siberian Federal University. All rights reserved

This work is licensed under a Creative Commons Attribution-Non Commercial 4.0 International License (CC BY-NC 4.0).

* Corresponding author E-mail address: Strombskoy@mail.ru 


\title{
Индукционный нагрев изложниц
}

\section{разливочного конвейера}

\author{
В.Н. Тимофеев ${ }^{a}$, \\ И.А. Стромбскойб \\ ${ }^{a}$ Сибирский федеральный университет \\ Красноярск, Российская Федераиия \\ ${ }^{\sigma} О О О «$ «УСАЛ ИТЦ» \\ Красноярск, Российская Федераиия
}

\begin{abstract}
Аннотация. В плавильно-литейном производстве алюминиевой чушки широко используются разливочные конвейеры. Алюминиевая чушка определенной формы и веса получается путем кристаллизации жидкого алюминия (расплава) в изложницах разливочного конвейера. По мере движения изложниц по конвейеру расплав в них постепенно затвердевает. В высокопроизводительных конвейерах для увеличения скорости охлаждения расплава изложницы двигаются по воде. Поэтому после освобождения изложницы от затвердевшей чушки в нее попадает вода. С целью исключения температурного шока и возможного выброса жидкого металла изложницы необходимо перед заливкой просушить и подогреть. В настоящее время на алюминиевых заводах для этого используют газовые горелки [1]. Целью данной работы является исследование возможности индукционного нагрева изложниц разливочного конвейера.

Расчет осуществляется с использованием рядов Фурье в комплексной форме и приближенными граничными условиями на поверхности ферромагнитных изложниц. Приближенные граничные условия позволяют избежать необходимости расчета электромагнитного поля в нелинейной ферромагнитной среде.

В нагреваемом объекте энергия индуцированного переменного электрического поля необратимо превращается в тепловую энергию. Эта диссипация тепловой энергии, приводящая к нагреву объекта, определяется наличием токов проводимости (вихревых токов).

Индукционный нагрев широко применяется в металлурги для плавления, нагрева и перемешивания электропроводящих тел. Метод основан на поглощении телами электромагнитной энергии переменного магнитного поля, создаваемого индуктором. Нагреваемое изделие располагается в непосредственной близости от индуктора. Существует много публикаций по аналитическому и численному анализу физических процессов в системе индуктор - нагреваемая заготовка. В данной работе проведен аналитический расчет электромагнитных процессов в системе индуктор - ферромагнитные изложницы разливочного конвейера. Аналитическое решение получено благодаря использованию приближенного граничного условия Л.Р. Неймана на поверхности нелинейных ферромагнитных изложниц.
\end{abstract}

Ключевые слова: разливочный конвейер, индукционный нагрев, система индуктор - изложница, алюминиевый слиток, магнитное поле.

Цитирование: Тимофеев, В.Н. Индукционный нагрев изложниц разливочного конвейера / В. Н. Тимофеев, И. А. Стромбской, А.Б. Алексеева // Журн. Сиб. федер. ун-та. Техника и технологии, 2021, 14(5). С. 583-589. DOI: $10.17516 / 1999-494 X-0335$ 


\section{The structure and the principle of operation of the filling conveyor with induction heating of the molds is described}

Figure 1 schematically shows the filling conveyor for the production of aluminum ingots. Here, 1 is a filling wheel; 2 is a mold; 3 is a water-cooling system; 4 is a solid ingot; 5 is a gas burner; 6 is an inductor of an alternating magnetic field.

The device works as follows. From the filling wheel 1, the melt enters the mold 2, which moves from point A to point $\mathrm{B}$. Along the way, the metal mill passes through a water-cooling system. The melt in the molds crystallizes and at point B the solid ingot 4 falls out of the mold and is placed in a bag for transportation. Gas burners 5 can be used to dry and heat the molds before pouring the melt at point A. In this paper, we will consider the possibility of using an induction heating system for molds. The variable magnetic field inductor 6 is installed at the bottom of the conveyor. The inductor 6 consists of a magnetic circuit 7 and a winding 8 laid in the grooves of the magnetic circuit. When the winding 8 is connected to an alternating voltage source, an electric current occurs in it, creating an alternating magnetic field. According to the law of electromagnetic induction, an alternating magnetic field induces eddy currents in steel mills, the energy of which leads to an increase in the temperature of the molds.

To increase the temperature of the mill by a value of $\Delta T_{21}=T_{2}-T_{1}$, an amount of energy (1) is required.

$$
\theta_{21}=m C_{p} \Delta T_{21},
$$

where $m$ - the weight of the mold, $\mathrm{kg}$;

$C_{p}$ - specific heat capacity, $\mathrm{J} / \mathrm{kg} * \mathrm{~K}$;

$T_{1}$ - the temperature of the mold at the point $\mathrm{G}$ (before entering the inductor zone), $\mathrm{K}$;

$T_{2}$ - the temperature of the mold at point $\mathrm{D}$ (at the exit from the inductor zone), $\mathrm{K}$.

The active power $P$ entering the mold from the inductor must ensure that the energy balance is maintained

$$
P t_{1}=\theta_{21}+\Delta P_{p} t_{2}
$$

where $t_{1}$ - the time of movement of the mold in the zone of the inductor, sec;

$t_{2}$ - the time of the mold movement from the inductor to the melt filling, sec;

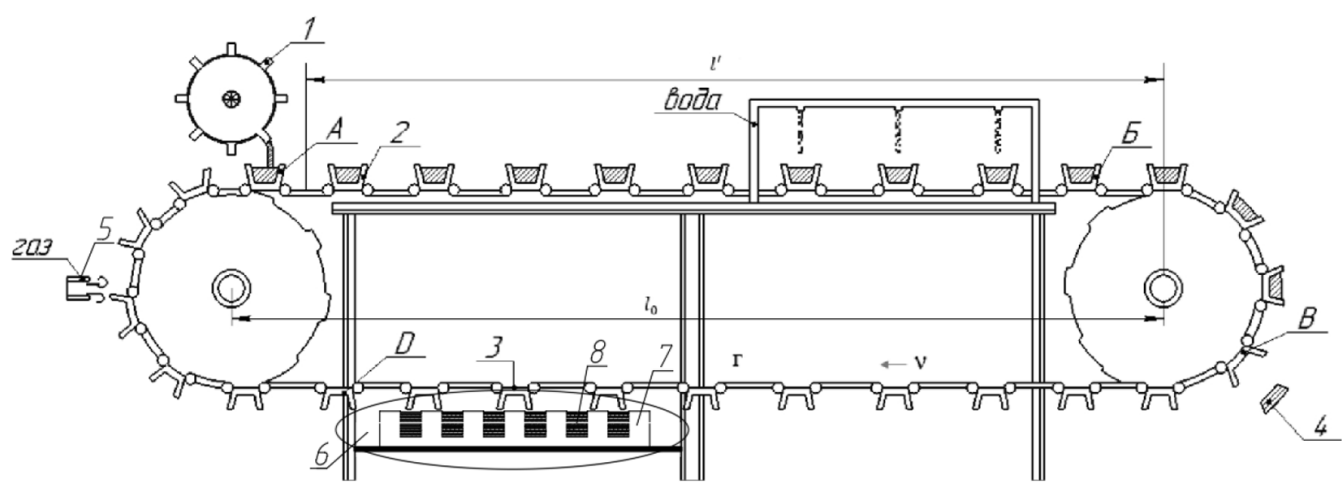

Fig. 1. Schematic drawing of the filling conveyor 
$\Delta P_{p}$ - the power of energy dissipation when cooling the mold, when moving from the inductor zone to the metal casting point (point A), WA.

\section{Computational and mathematical models of the inductor-mill system}

When constructing the computational model, we consider the following assumptions [2]:

1. We present the molds as a homogeneous ferromagnetic medium with a specific electrical conductivity of $\gamma_{c}$ and a magnetic permeability of $\mu_{a}$, as a function of the magnetic field strength of $\mu_{a}=\mu_{0} \cdot \mu_{c}=f(H)$. The homogeneous medium moves comparative to the inductor at a constant speed $v$.

2. The magnetic core of the inductor is represented by a smooth medium with a specific electrical conductivity of $\gamma_{c}=0$, and a magnetic permeability of $\mu_{c}=\infty$, the grooves with the winding conductors are conditionally accepted as surface currents with a linear density, A / m.

$$
\dot{J}=J e^{i\left(\omega_{0} t-\alpha x\right)},
$$

where $\omega_{0}=\omega \mathrm{s} ; \omega-$ angular frequency, $\bar{c} ; s-\operatorname{slip} ; \alpha=\pi / \tau$.

$$
s=\frac{s \tau f-v}{s \tau f} ; J=\frac{m W_{1} k_{o \sigma 1}}{\tau} \cdot I_{1} .
$$

The dimensions of the device in the transverse direction (y-axis) are assumed to be infinitely large. The coordinate system is considered to be rigidly connected to the ferromagnetic medium.

The calculation model that meets the accepted conditions is shown in Figure 2.

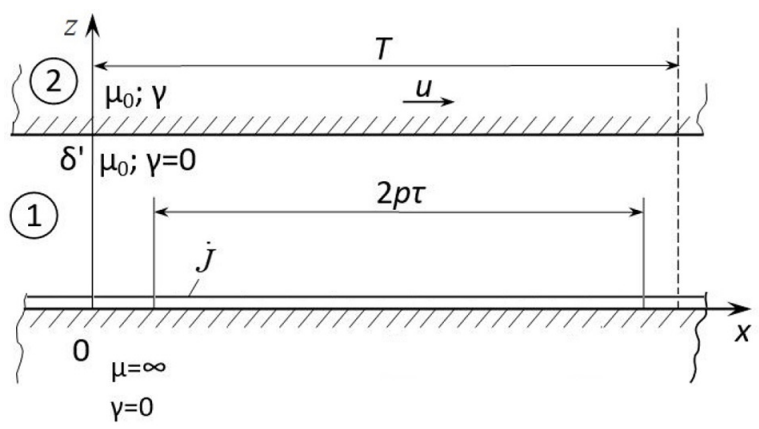

Fig. 2. Calculation model of the system of inductor-ferromagnetic molds

The vectors of the electric and magnetic field strengths have component values

$$
\dot{\bar{E}}(t, x, z)=\bar{e}_{y} \cdot \dot{E}_{y} ; \bar{H}(t, x, z)=\bar{e}_{x} \dot{H}_{x}(t, x, z)+\bar{e}_{z} \dot{H}_{z}(t, x, z) .
$$

It is advisable to solve the problem of calculating the electromagnetic field through the complex component of the electric field strength $\dot{\bar{E}}(x, z)$, which can be represented in accordance with (3).

$$
\dot{E}_{y}(x, z)=\tilde{E}_{y}(z) e^{\alpha x}
$$

The mathematical model for determining $\tilde{E}_{y}(z)$, in accordance with the calculation model, has the form: 
The Laplace equation

$$
\frac{d^{2} \tilde{E}_{y}}{d z^{2}}-\alpha^{2} \tilde{E}_{y}=0 .
$$

Boundary conditions

$$
\tilde{H}_{x}(0)=\dot{J} ; \tilde{E}_{y}(\delta)=(1+i 0,6) \sqrt{\frac{\omega \mu_{c}(H)}{\gamma_{c}}} \cdot \tilde{H}_{x}(\delta),
$$

where $\mu_{c}(H)$ is the value of the magnetic permeability on the surface of the ferromagnetic medium, determined from the universal magnetization curve by the effective value of the magnetic field strength $H_{0}$ [3]. Due to the pronounced surface effect $H_{0} \approx H_{x}$. Expression 11 is an approximate boundary condition of L. R. Neumann [4].

From Maxwell's equation $\operatorname{rot} \dot{\bar{E}}=-i \omega \mu_{0} \dot{H}$, we get

$$
\tilde{H}_{x}=\frac{1}{i \omega \mu_{0}} \cdot \frac{\partial \tilde{E}_{y}}{\partial z} .
$$

Considering (12), the boundary conditions (10) and (11) are transformed to the form

$$
\frac{d \tilde{E}_{y}}{d z}(0)=i \omega \mu_{0} j ; \tilde{E}_{y}(\delta)=-\underline{z}_{c} \cdot \frac{\partial \tilde{E}_{y}}{\partial z}(\delta),
$$

where

$$
\underline{z}_{c}=(i-0,6) \frac{1}{\mu_{0} \sqrt{\omega}} \sqrt{\frac{\mu_{c}(H)}{\gamma_{c}}} .
$$

The presented mathematical model (9-15) allows us to obtain an expression for the electric field strength in the form:

$$
\tilde{E}_{y}(z)=\frac{i \mu_{0} \omega J}{\alpha} \cdot \frac{\operatorname{sh} \alpha(z-\delta)-\alpha \underline{z}_{c} \operatorname{ch} \alpha(z-\delta)}{\operatorname{ch} \alpha \delta+\alpha \underline{z}_{c} \operatorname{sh} \alpha \delta} .
$$

In accordance with (12), we write the expression for the component of the magnetic field strength

$$
\tilde{H}_{x}(z)=J \cdot \frac{\operatorname{ch} \alpha(z-\delta)-\alpha \underline{z}_{c} \operatorname{sh} \alpha(z-\delta)}{\operatorname{ch} \alpha \delta+\alpha \underline{z}_{c} \operatorname{sh} \alpha \delta} .
$$

We introduce a dimensionless coefficientf

$$
\zeta=\frac{\pi}{\tau \mu_{0} \sqrt{\omega}} \sqrt{\frac{\mu_{c}(H)}{\gamma_{c}}} .
$$

In this case, in accordance with (15), we have

$$
\alpha \underline{z}_{c}=-0,6 \zeta+i \zeta .
$$

On the surface of ferromagnetic molds $z=\delta$, the expression (17) takes the form

$$
\begin{array}{r}
\tilde{H}_{x}(\delta) \approx H_{0}=J \cdot \frac{1}{c h \alpha \delta+\alpha \underline{z}_{c} s h \alpha \delta} . \\
-587-
\end{array}
$$


From here we get

$$
J=H_{0} \cdot|\operatorname{ch} \alpha \delta+(-0,6 \zeta+i \zeta) \operatorname{sh} \alpha \delta| .
$$

Equation (21) is non-linear, since the quantity $\zeta$ included in 1 depends on $\sqrt{\frac{\mu_{c}}{\gamma_{c}}}$.

For a wide class of steels, the dependence $\sqrt{\frac{\mu_{c}}{\gamma_{c}}}=f\left(H_{0}\right)$ is presented in Table 1 [2].

The third row of Table 1 shows the values of the relative coefficient $\zeta$, calculated by (18), for the following values: $\omega=2 \pi \mathrm{f}=314 \cdot c^{-1} ; \tau=0,2 \mathrm{~m} ; \mu_{0}=4 \pi \cdot 10^{-7} \mathrm{Gn} / \mathrm{m}$. The fourth line shows the value of the current density $J$, determined by (21).

For a rivran value of the linear current load $J$, we determine the value $H_{0}$ from Table 1 and find the value $\sqrt{\frac{\mu_{c}}{\gamma_{c}}}$.

Table 1. Basic parameters

\begin{tabular}{|c|c|c|c|c|c|c|c|c|c|c|c|c|c|c|}
\hline$H_{0} \cdot 10^{2}, \mathrm{~A} / \mathrm{m}$ & $\infty$ & 으 & ㄱ & i & ㅇ & in & $\stackrel{n}{n}$ & \& & ¿ & \& & 8 & ¿ & 号 & 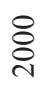 \\
\hline $\begin{array}{c}\sqrt{\frac{\mu_{c}(H)}{\gamma_{c}}} \cdot 10^{-4}, \\
\text { Оm·сек }\end{array}$ & $\frac{n}{0}$ & $\frac{\Delta}{0}$ & $\overline{0}$ & 8 & $\begin{array}{l}\text { OD } \\
0 \\
0\end{array}$ & : & है & $\begin{array}{l}\text { है } \\
\text { o. }\end{array}$ & ڤે & $\hat{\tilde{\delta}}$ & $\stackrel{\widehat{o}}{0}$ & $\begin{array}{l}\bar{\delta} \\
0 \\
0\end{array}$ & $\stackrel{\infty}{0}$ & $\begin{array}{l}\stackrel{2}{0} \\
0 \\
0\end{array}$ \\
\hline$\zeta$, o. e. & $\underset{\stackrel{\infty}{+}}{\stackrel{\infty}{+}}$ & $\underset{f}{\stackrel{\Xi}{\Xi}}$ & $\begin{array}{l}\text { ते } \\
\text { ल) }\end{array}$ & $\begin{array}{l}\text { ?q } \\
\text { in } \\
\text { in }\end{array}$ & 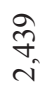 & $\begin{array}{l}\hat{n} \\
i\end{array}$ & $\stackrel{+}{\stackrel{f}{=}}$ & $\stackrel{\infty}{\sim}$ & $\stackrel{\circ}{I}$ & $\hat{o}$ & $\begin{array}{l}\tilde{\hat{\sigma}} \\
\hat{0}\end{array}$ & 苛 & ते & $\begin{array}{l}\text { f } \\
\stackrel{f}{\circ}\end{array}$ \\
\hline$J \cdot 10^{2}, \mathrm{~A} / \mathrm{m}$ & $r$ & $a$ & ニ & i & $m$ & 寸 & $\ddot{\infty}$ & б & $\stackrel{\circ}{\simeq}$ & $\underset{\sim}{\infty}$ & $\stackrel{゚}{f}$ & $\hat{2}$ & 守 & $\stackrel{\check{n}}{2}$ \\
\hline
\end{tabular}

\section{Electromagnetic power of the inductor}

The complex electromagnetic power transmitted by the inductor to the gap is equal to

$$
\underline{S}^{\ni M}=-l \cdot L \cdot \tilde{E}_{y}(0) \cdot \stackrel{*}{J},
$$

where, $l$ and $L$ are the width and length of the inductor, $\mathrm{m}$; $J$ is the conjugate complex of the current density.

From (16) we write

$$
\tilde{E}_{y}(0)=-i \frac{\mu_{0} \omega J_{n}}{\alpha} \cdot \frac{\operatorname{sh} \alpha \delta+\underline{z}_{c} \alpha \operatorname{ch} \alpha \delta}{\operatorname{ch} \alpha \delta+\underline{z}_{c} \alpha \operatorname{sh} \alpha \delta}
$$

Substituting (23) in (22), we write the expression for the electromagnetic power

$$
\underline{S}^{\ni M}=P^{\ni M}+i Q^{\ni M}=\frac{l L \mu_{0} \omega \tau}{\pi} \cdot J^{2} \cdot(X+i Y),
$$

где

$$
(X+i Y)=i \frac{\operatorname{sh} \alpha \delta+\underline{z}_{c} \alpha \operatorname{ch} \alpha \delta}{\operatorname{ch} \alpha \delta+\underline{z}_{c} \alpha \operatorname{sh} \alpha \delta}
$$



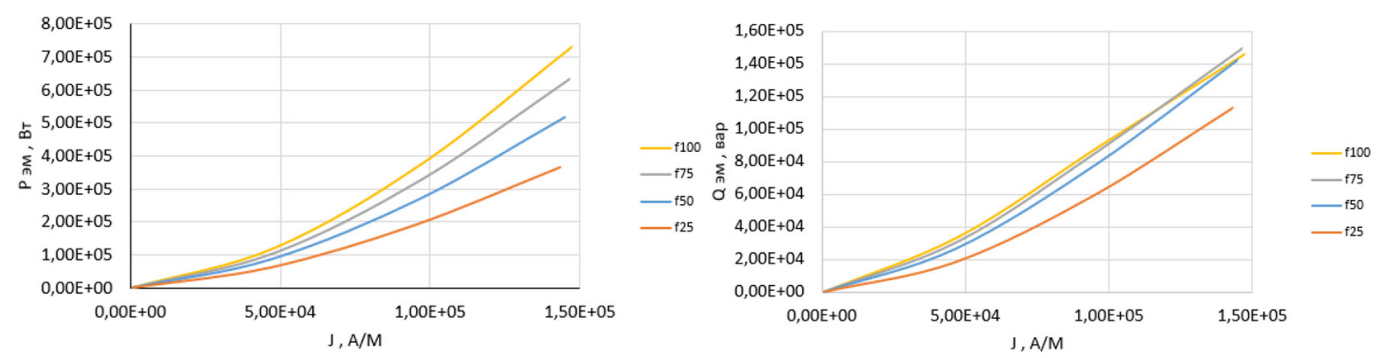

Fig. 3. Dependence of active and reactive power on frequency

Here, the active and reactive electromagnetic power.

$$
P^{\ni \mathrm{M}}=\operatorname{Re}\left\{\underline{S}^{\ni \mathrm{M}}\right\} \text { и } Q^{\ni \mathrm{M}}=\operatorname{Im}\left\{\underline{S}^{\ni \mathrm{M}}\right\} .
$$

Fig. 3 shows the dependences of the active $P^{\ni \mathrm{M}}$ and reactive $Q^{\ni \mathrm{M}}$ powers on the linear current density, at different frequencies of $f, \mathrm{~Hz}$.

\section{Conclusions}

1) On the basis of the accepted assumptions, a mathematical model is constructed for determining the vectors of the electromagnetic field, in which the nonlinear properties of the ferromagnetic medium are considered by using the approximate boundary condition of L.R. Neumann.

2) The dependences between the magnetic field strength and the corresponding magnetic permeability value on the linear current density of the inductor at different values of parameter $\zeta$ are obtained, all values are given in Table 1 .

3) At the required value of the active power providing the set temperature of the mold at the melt supply point, the value of the linear current load of the inductor is determined and all the electromagnetic characteristics of the inductor - mold system are calculated.

\section{References}

[1] Patent of the Russian Federation No. 2014146976/02, 2014.11.21. Complex for pouring liquid metal into molds on a conveyor / / RU2 $578272 \mathrm{C1} /$ Trusov Vladimir Alexandrovich

[2] Voldek A.I. Electric machines: Textbook for electrical engineering. spec. vuzov. Leningrad: Energy, 1974. 839 p.

[3] Maergoiz I.D. Calculation of the surface effect in ferromagnetic bodies covered with a conducting layer. Electricity, 1970, 2, 83-86 p.

[4] Neiman L. R. Surface effect in ferromagnetic bodies. M.: Gosenergoizdat, 1949. 190 p. 